\title{
THE EMPIRICAL EVIDENCE ON TAXPAYERS' INTENTION TO CLAIM ZAKAT PAYMENT AS A TAX REBATE
}

\author{
Izlawanie Muhammad* \\ Universiti Sains Islam Malaysia \\ Nur Shahira Mohamad Nor \\ Universiti Sains Islam Malaysia
}

\begin{abstract}
Malaysia is one of the Islamic countries that integrate zakat in the tax system; Muslim individual taxpayers can minimize tax payment by claiming zakat paid as a tax rebate which is deducted from the amount of total income tax. Although zakat rebate has been applied in the tax system more than 20 years, there is lacking research on its effectiveness to increase zakat and tax payment compliance. This study is a step forward for more zakat rebate and the integration of zakat and tax research. The objective of this study is to examine Muslim individual taxpayers' intention in claiming zakat as a tax rebate. This study adopts the variables in the Theory of Planned Behaviour (i.e. attitude, subjective norm, perceived behavioural control) and include knowledge as the variables. The quantitative research methodology was applied by using a questionnaire. This study found that all variables have significant influence on Muslim individual taxpayers' intention in claiming zakat payment as a tax rebate. The results of this research not only expand the minimal literature on the integration of zakat in the tax system, but also provide empirical evidence to the tax and zakat authorities in understanding the behaviour of Muslim individual taxpayers.
\end{abstract}

Keywords: Zakat, Tax Rebate, Theory of Planned Behaviour, Knowledge.

Received: 14 August 2019

Accepted: 10 May 2021

https://doi.org/10.33736/ijbs.3748.2021

\section{INTRODUCTION}

Paying zakat is one of Muslims' obligations to Allah" The responsibility to pay zakat is mentioned by Allah 30 times in the al-Quran and it is supported by several hadith from Rasulullah Zakat has compounded benefits to the zakat payers, society and nation. Allah ${ }^{2}$ gives great rewards in this life and life hereafter to compliant Muslims. Allah promised that Muslims who pay zakat will never become poor; instead, they will be given more rewards in various forms (i.e. health, money, promotion, kindness) and in the life hereafter, they will be placed in heaven full of greatest things beyond their expectations. For the eight group of asnaf or zakat recipients, zakat contributions help them to resolve monetary issues and help them to build a sustainable future. The eight group of asnaf or recipients are the poor, destitute, amil (zakat collector), muallaf (nonMuslims who embraced Islam), riqab (persons who want to free themselves from bondage of

\footnotetext{
- Corresponding author: Faculty of Economics and Muamalat, Universiti Sains Islam Malaysia, 71800 Nilai, Negeri Sembilan, Malaysia; Tel: +6067986437; Email: izlawanie@usim.edu.my
} 
slavery), gharimin (persons in debt but need assistance for their basic needs), fisabilillah (persons who strives in the cause of Allah for the betterment of community) and ibnusabil (stranded travellers on permissible journey). In the long run, zakat contributions contribute for development of society, economic and nation.

There are two types of zakat namely zakat fitr and zakat on wealth. Zakat fitr is compulsory for each individual Muslim (i.e. infant, teenager, adult and elderly). Zakat fitr is paid during the month of Ramadan or latest by early morning of first Syawal, immediately before the Eid Fitri prayer. Zakat on wealth, in contrast, is paid by Muslims throughout the year when they earned or owned certain types of wealth including employment and business income, savings, crops and agriculture, gold and silver, shares and natural resources. Zakat on wealth must be paid by Muslims when they met five conditions: Muslim, free (i.e. not a slave), the wealth is ultimately belong to the person, complete haul (i.e. minimum period the person owns the wealth) and complete nisab (i.e. minimum amount of wealth / property before the person should pay zakat). The main objective of zakat is sharing of wealth between rich and unfortunate Muslims.

Muslims who live in a country that imposed tax law have another responsibility of sharing their wealth. Tax is a compulsory contribution levied by the government on persons, for example, individual, corporation and trust (Singh, 1998; Mikesell, 2003). The government used the money for administrating the country (i.e. remuneration and security) and providing public facilities (i.e. health and transportation). Muslims must comply with both responsibilities which they could be paying both zakat and tax from the same source of income particularly employment and business.

Malaysia is a Muslim country that collects tax from the society. Two types of taxes imposed by the Malaysian government are direct and indirect tax which governed by the Inland Revenue Board of Malaysia (IRBM) and the Royal Malaysia Customs Department (RMCD) respectively. IRBM collects income tax, real property gains, petroleum and stamp duty while RMCD collects the goods and services tax and customs duty. With the objectives to reduce burden of paying of zakat and tax by individual Muslims and to promote tax compliance, the IRBM implemented zakat rebate system in 2001. Under the system, Muslim individual taxpayers can minimize tax payment by claiming zakat paid as a tax rebate which is deducted from the amount of total income tax.

After more than 20 years of the integration of zakat in the Malaysia tax system, there is still lacking statistical analysis on zakat rebate and empirical evidence of taxpayers' behaviour in claiming the rebate. Little is known about total government loss from the zakat rebate and the efficiency of the system in promoting both zakat and tax compliance. This study aims to contribute to the minimal study on the integration of zakat in the Malaysia tax system. Rather than analysing zakat and tax governance issue which obviously lacking published statistics and information, this study is focusing on taxpayers' behaviour as it is one of the major factors that contribute to the effectiveness of zakat and tax system. This study examines taxpayers' attitude, subjective norm and perceived behavioural control and knowledge in claiming zakat as a tax rebate. The first three variables are adopted from the Theory of Planned Behaviour (TPB) which is the most referred theory in examining human's behaviour (Ajzen, 1991). 


\section{LITERATURE REVIEW}

\subsection{Zakat as A Tax Rebate}

Malaysia is one of the few Islamic countries that integrate zakat in its tax system. The IRBM implemented the zakat rebate into the tax system in 2001; Section 6A(3) of the Income Tax Act (ITA) 1967 outlines that Muslim individual taxpayers can deduct the amount of zakat paid to zakat authorities from the total income tax. The types of zakat paid include zakat fitr and all types of zakat on wealth. Other than payment to zakat authorities, there are several other conditions that must be fulfilled before the taxpayers can claim the rebate. First, except for zakat fitr, the original zakat payment receipt from zakat authorities must be issued in the name of the taxpayer. Second, zakat rebate must be claimed in the basis year for the year of tax assessment. For example, zakat paid on 14 December 2020 must be claimed for 2020 tax assessment. Finally, the amount of zakat rebate is limited to the total income tax in the year of assessment; any excess amount cannot be carried forward to the following year of assessment or claim as tax repayable (Muhammad et al., 2017).

The IRBM does not publish statistical data on total zakat rebate claimed by taxpayers. Samad, Ariff and Nassir (2016) reported that IRBM lost a total of more than RM1.61 billion from zakat rebate. The rebate was claimed by individual taxpayers with business and without business income. However, the statistical data from the study was not supported by any reference. Hence, accuracy and authenticity of the data are questionable. Lack of statistical data may contribute to the lack of study on the integration of zakat in the tax system. In fact, there is no published studies that present empirical evidence on zakat payers' and taxpayers' behaviour on claiming zakat as a tax rebate in Malaysia.

Many studies focused on zakat or tax compliance behaviour (e.g. Bakar \& Rashid, 2010; Damayanti et al., 2015; Kusumawati et al., 2014; Palil et al., 2013; Ramayah et al., 2009; Saad, 2012). From these studies, only Bakar and Rashid (2010) included zakat rebate in tax assessment as one of the factors that influence zakat payers' compliance. The majority (i.e. 97\%) of the respondents were both zakat payer and taxpayers. The study found that zakat rebate knowledge among zakat payers were low and did not influence their zakat compliance behaviour. In other words, zakat rebate is not a prime factor for zakat payment. Instead, the respondents had strong and sincere commitment towards their religion in paying zakat.

Instead of examining zakat payers' behaviour, Al-Mamun and Haque (2015) explored Muslim consumers' perception towards zakat rebate in Malaysia. The study found that zakat knowledge, tax knowledge, halal-haram aspects, legal consciousness and religious consciousness had positive influence towards Muslim's consumer perception towards tax through the zakat system. However, the respondents' perception did not determine the intention and behaviour of individuals towards this system; perception is only an opinion of the respondents who may not have experience in using the system.

More studies on zakat rebate are essential to understand zakat payer and taxpayers' knowledge, to examine the effectiveness towards tax and zakat compliance, to analyse the loss of tax collections and to examine zakat payer and taxpayers' behaviour in claiming the rebate. The present study is 
the first empirical study that examines individual Muslim's intention to claim zakat payment as a tax rebate in Malaysia. This study adopts the variables from the TPB (i.e. attitude, subjective norm and perceived behavioural) and includes knowledge as the factors that influence individual Muslim taxpayers' intention to claim zakat payment as a tax rebate. The findings from this study will contribute to the scarce of zakat-taxation literature.

\subsection{Theory of Planned Behaviour}

The Theory of Planned Behaviour examines individuals' intention in performing their behaviour (Fishbein \& Ajzen, 1975). TPB assumes that the behaviour of a person is determined not only by the intention but also the ability of that person as well as having control in performing the behaviour. Individual's behavioural intentions are predicted based on three determinants - attitude, subjective norm and perceived behavioural. TPB is widely adopted in various area of studies including marketing (e.g. Pappas, 2016), health (e.g. De Bruijn, 2010), zakat compliance (e.g. Huda et al., 2012) and tax compliance (e.g. Damayanti et al., 2015; Kusumawati et al., 2014; Ramayah et al., 2009; Shaharuddin et al., 2012). Some of the studies included other variables in examining individuals' intention in performing their behaviour.

Although TPB has been widely adopted by researchers in various research areas, TPB has not been tested in zakat rebate study. This study adopts the TPB to examine Muslim individual taxpayers' intention in claiming zakat as a tax rebate. Other than the three variables in TPB, this study also includes knowledge as an additional dependent variable. The following literature review on the variables will focus on tax and zakat studies as the most related areas to this present study.

\subsection{Attitude}

Attitude is a belief in favourable outcomes - the more favourable the possibility of the outcomes, the stronger the intention to do the behaviour will remain, vice versa (Shook \& Bratianu, 2010). Eagly and Chaiken (1993) stated that attitude is a psychological bias which is approved in the valuation on certain entities with some degree of good deed or disfavour. Attitude also assist people to define how they can observe and act towards a situation (Pickens, 2009).

Several studies examined attitude as a factor that influence taxpayers' compliance behaviour (Kusumawati et al., 2014; Saad, 2012; Shaharuddin et al., 2012). The researchers predicted that taxpayers intend to comply with tax requirements when they have positive attitude towards tax system. The researchers examined different group of taxpayers including sole-proprietor (Shaharuddin et al., 2012), employee (Kusumawati et al., 2014) and corporate taxpayers (Saad, 2012) The studies found a similar finding - attitude was significantly and positively influence taxpayers' tax compliance decision making and their willingness to comply with tax laws.

Meanwhile in zakat compliance, researchers (Abashah et al., 2018; Huda et al., 2012; Mokhtar et al., 2018; Sapingi et al., 2011) examined the relationship between attitude and zakat compliance behaviour and they found a positive and significant relationship. Huda et al. (2012) even found that attitude had the highest score compared to subjective norm and perceived behavioural. This shows that attitude is a significant factor in influencing a person's intention. 


\subsection{Subjective Norm}

Subjective norm is described as individual's intention is influenced by their reference group in performing a certain behaviour (Bidin et al., 2009). It can be simply understood as a perception of people's views and thoughts in doing something because of the advice or pressure or from other people such as family and friends (Ajzen \& Fishbein, 1980). These important people are called as a referent group. An individual's perception towards the referent group can play an important role on the individual to perform a particular intention behaviour for example the intention to comply with tax and zakat law.

In the context of taxation, Shaharuddin et al. (2012) found that subjective norm positively influenced sole proprietors' the intention to comply with tax law. However, Kusumawati et al. (2014) found that subjective norm did not influence hotel taxpayers in paying tax to the government. Researchers also found mixed result in zakat compliance studies. While Amilahaq and Ghoniyah (2019); Bidin et al. (2009); Mokhtar et al. (2018); Zainol (2008) found a positive relationship, Huda et al. (2012) and Sapingi et al. (2011) found an adverse result - subjective norms did not influence zakat payer's intention to pay zakat. However, there is no published research that examine the influence of subjective norm towards claiming zakat rebate.

\subsection{Perceived Behavioural Control}

According to Ajzen (1991), perceived behavioural control can be defined as one's perceived ease or difficulty in acting out one's particular intention and behaviour. To explain this perception of perceived behavioural control, Ajzen (1991) differentiated it from the locus of control recommended by Rotter (1966). Locus of control is related to one's belief which is relatively changing in all situations. Linden (2011) also stated that perceived behavioural control can occur in a particular action. This variable may change depending on the situations to be achieved.

Khaddafi et al. (2014) and Sapingi et al. (2011) found perceived behavioural control had positive and significant relationship towards the intention of traders and academicians to pay zakat respectively. Similarly, in tax compliance studies, Kusumawati et al. (2014) and Shaharuddin et al. (2012) also found a positive and significant relationship between taxpayers' intention and tax compliance behaviour. In the context of zakat rebate, a taxpayer has the ability to claim zakat rebate when the claiming procedure is easy and under the taxpayer's control. As has been explained earlier, taxpayer can claim a zakat rebate in a year of assessment when the taxpayer keeps the original receipt and it is issued under the taxpayer's name, except for zakat fitr receipt. This procedure is similar with claiming tax reliefs, for example, purchased of books and computer. In the tax e-filing, zakat rebate can be claimed by entering the amount paid during the year. However, if zakat is paid through salary deductions, the zakat amount is automatically captured in the tax efiling system. Farah et al. (2019) found that the majority of respondents have opted for zakat payment through salary deductions.

\subsection{Knowledge}

Knowledge is the most important resource and basic part to obtain intangible assets and relatedness (Grant, 1996). Knowledge can be simply understood as the conditions to know something in certain 
circumstances. Some scholars agree knowledge is one of the primary resources for creating value; to gain something or new information and getting competitive advantages (Kogut \& Zander 1992).

Kamil (2002) and Farah et al. (2019) showed that knowledge is one of the important factors that influenced Muslims to pay zakat. They concluded that the level of knowledge played a major role towards their behaviour of zakat payment. Both studies also mentioned that knowledge about zakat gave an impact on the collection of zakat among the zakat payers. Zakat and tax knowledge can be obtained through formal learning (e.g. attending courses or seminar) or informal learning (e.g. advice from the zakat or tax authorities, friends or family) (Farah et al., 2019).

In the context of taxation, Palil et al. (2013) found that tax knowledge influenced tax compliance among the taxpayers. The result indicated that the level of tax knowledge is significant to ensure that the tax collection will be higher. The taxpayers will be able to assess their liability correctly and fulfil their obligation to the government. Mukhlis et al. (2015) also found that tax knowledge gave a positive impact on tax compliance. The study also found that tax knowledge had the highest score compared to other factors. An exploratory study by Al-Mamun and Haque (2015) also included knowledge as one of the variables in exploring Muslim consumer's perception towards tax deduction through zakat. The result showed that knowledge influenced Muslim consumers' perception toward zakat rebate system in Malaysia.

\section{CONCEPTUAL FRAMEWORK OF THE STUDY}

The proposed framework of this study is constructed in references to the literature review. The framework examines the three variables of TPB and knowledge as the factors that influence taxpayers' intention to claim zakat payment as a tax rebate. The framework is presented in Figure 1 below.

Figure 1: Conceptual Framework

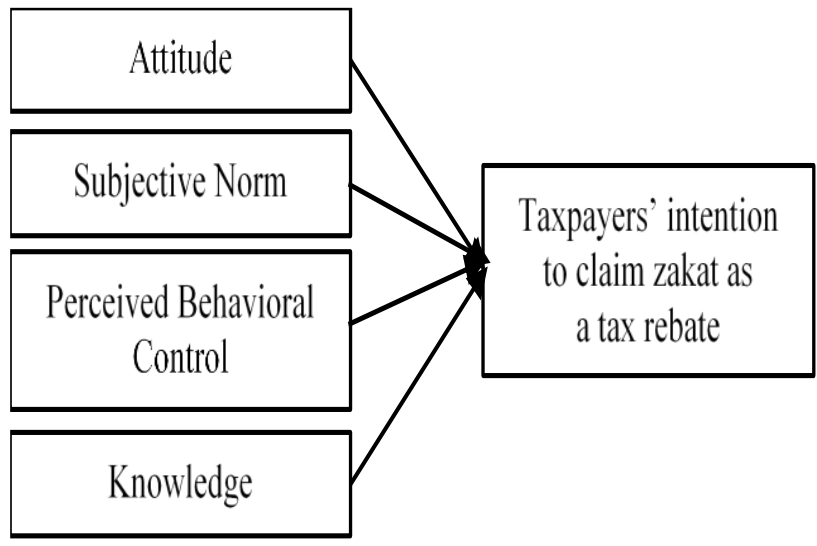


The following hypotheses are developed based on the conceptual framework that is illustrated in Figure 1:

\author{
H1: Attitude positively influence taxpayers' intention to claim zakat as a tax rebate \\ H2: Subjective norm positively influence taxpayers' intention to claim \\ zakat as a tax rebate. \\ H3: Perceived behavioural control positively influences taxpayers' intention to \\ claim zakat as a tax rebate \\ H4: Knowledge positively influence taxpayers' intention to claim zakat as a tax rebate.
}

\title{
4. RESEARCH METHODOLOGY
}

This study adopts the quantitative research methodology to test the hypotheses. A survey questionnaire that consists of four sections were constructed and the questions for the four variables were adopted from the literature. The target population of this study is individual Muslim resident taxpayers in Selangor. The respondents must not have business income and eligible to pay both tax and zakat. The respondents must also earn at least RM34,000 income per year because they are generally eligible to pay both tax and zakat (IRBM, 2015).

Purposive sampling technique was used because it is convenient and the researchers able to assess the elements of the population (Salkind, 2014). Two methods of questionnaire distribution were conducted. First was the paper-based and the other was the online-survey. For the paper-based survey, the researcher distributed the questionnaire directly to 500 potential respondents personally. The potential respondents worked in four industries - accounting, banking, media an entertainment and academic. For the online survey, the researchers sent e-mails to 100 academicians from three universities in Selangor - Universiti Malaya, International Islamic University Malaysia and Universiti Selangor. The three universities selected are different from those chosen for the paper-based survey to avoid multiple participation of the respondents in the study. The researchers obtained their emails from the Universities' websites. The questions were in keyed in the Google Docs to get the respondents' answers.

The response rate was $72.5 \%$. A total of 435 completed and usable questionnaires received which comprised of 390 respondents from the paper-based survey and 45 respondents from the e-mail survey. Statistical Package for Social Sciences (SPSS) version 23 was used to analyse the data. Selected items of the intention of taxpayers to pay zakat as a tax rebate were chosen, and the means of the items were compared between the early response and late response samples. There were 150 cases from the early response group and 50 cases from the late response group. To decide whether the groups were significantly different from each other, the two-tailed p-value was examined. As indicated in Table 1, the entire item showed non-significant p-values (all items indicated p-values $>0.05$ ), which means that the early response and late response groups were not significantly different. Therefore, it can be concluded that non-response bias was not a concern in this study for the analyses of taxpayers' intention to claim zakat as a tax rebate. 
Table 1: $T$-Test Results for Early and Late Responses for Items Measuring Taxpayers' Intention to Claim Zakat As A Tax Rebate

\begin{tabular}{lccccc}
\hline \multirow{2}{*}{ Item } & \multicolumn{2}{c}{ Early Response $(\boldsymbol{N}=\mathbf{1 5 0})$} & \multicolumn{2}{c}{ Late Response $(\boldsymbol{N}=\mathbf{5 0})$} & \multirow{2}{*}{$\boldsymbol{p}$-value } \\
\cline { 2 - 5 } & Mean & SD & Mean & SD & \\
\hline Attitude & 3.61 & 0.93 & 3.39 & 0.94 & 0.13 \\
Subjective Norm & 4.19 & 0.94 & 4.09 & 0.92 & 0.52 \\
Perceived Behavioural & 4.25 & 0.83 & 4.04 & 0.89 & 0.12 \\
Control & 4.05 & 0.94 & 3.89 & 0.980 & 0.30 \\
Knowledge & 3.72 & 0.98 & 3.57 & 0.86 & 0.33 \\
Intention & & & & \\
\hline \hline
\end{tabular}

After the t-test, another five tests were conducted namely demographic, descriptive, validity, reliability and multiple regression analysis. The tests provide the demographic characteristics of the respondents, summary of the statistics (e.g. mean, median, and standard deviation), accuracy of data, consistency and stability measure and anticipation between the dependent variable and combination of independent variables respectively.

\section{DATA ANALYSIS AND RESULT}

\subsection{Demographic Analysis}

Table 2 shows the descriptive analysis of the respondents in terms of gender, age, education level, employment sector, employment industry, and total income per year in Ringgit Malaysia (RM).

Table 2: Demographic Profile of Respondents

\begin{tabular}{lcc}
\hline \hline Description & Frequency & Percentage (\%) \\
\hline Gender & 230 & 52.9 \\
Male & 205 & 47.1 \\
Female & 435 & 100 \\
Total & & \\
\hline Age & 101 & 23.2 \\
$20-29$ & 157 & 36.1 \\
$30-39$ & 134 & 30.8 \\
$40-49$ & 43 & 9.9 \\
50 above & 435 & 100 \\
Total & & \\
Education Level & 42 & 9.7 \\
Diploma & 238 & 54.7 \\
Degree & 93 & 21.4 \\
Master & 62 & 14.3 \\
PhD & 435 & 100 \\
Total & & \\
\hline Employment Sector & 129 & 29.7 \\
Government & 278 & 63.9 \\
Private & 19 & 4.4 \\
Self-employed & 9 & 2.1 \\
Others & & \\
\hline
\end{tabular}




\begin{tabular}{lcc}
\hline \hline Description & Frequency & Percentage (\%) \\
\hline Total & 435 & 100 \\
\hline Employment Industry & & \\
Audit \& Accounting & 58 & 13.3 \\
Banking & 137 & 31.5 \\
Telecommunication & 52 & 12.0 \\
Academic & 155 & 35.6 \\
Others & 33 & 7.6 \\
Total & 435 & 100 \\
\hline Total Income per Year & & \\
RM 30,000-RM 40,000 & 57 & 13.1 \\
RM 40,001-RM 50,000 & 167 & 38.4 \\
RM 50,001-RM 60,000 & 164 & 37.7 \\
RM 60,001 above & 47 & 10.8 \\
Total & 435 & 100 \\
\hline \hline
\end{tabular}

From 435 respondents, 230 are male (52.9\%) and 205 are female (47.1\%). The age group that obtained the highest percentage of respondents is 30-39 years old with $36.1 \%$ (157 respondents). This is followed by the 40-49 years old age group with 30.8\% (134 respondents) and 20-29 years old age group with $23.2 \%$ (101 respondents). Finally, the respondents who are 50 years old and above represent the lowest percentage at 9.9\% (43 respondents). Regarding the respondents' education level, the majority of the respondents (54.7\% or 238 respondents) have a degree. This is followed by $21.4 \%$ or 93 respondents who have a master's qualification at and $14.3 \%$ or 62 respondents with a $\mathrm{PhD}$. The remaining respondents $(9.7 \%$ or 42 respondents) hold a diploma qualification.

The results indicate that most of the respondents are from the private sector with 256 respondents or $58.9 \%$ while 151 respondents $(34.7 \%$ ) are from the government sector, all of whom are the academicians. Next, 19 respondents $(4.4 \%)$ are self-employed, and finally, the smallest percentage belongs to other sectors, $2.1 \%$ or nine respondents. The results also illustrate that the most represented employment industry is the academic industry with 155 respondents $(35.6 \%)$. Then, it is followed by the banking industry with 137 respondents or 31.5\%. Fifty-eight respondents $(13.3 \%)$ are from the audit and accounting industry, while another 52 respondents (12.0\%) are from the telecommunication industry. Finally, other industries have the smallest representation with 33 respondents $(7.6 \%)$.

This study required all the respondents to earn employment income of at least RM34,000 per year. The results show that the highest number of respondents earn an annual income of RM40,001RM50,000 with 167 respondents (38.4\%). This is followed by the income range of RM50,001RM60,000 per year, which is attributed to 164 respondents (37.7\%). Next, 57 respondents $(13.1 \%)$ fall in the annual income range of RM30,000-RM40,000 and finally, the smallest number of respondents (47 respondents or 10.8\%) earn above RM60,001 per year.

\subsection{Reliability Analysis (Independent and Dependent Variables)}

The purpose of reliability analysis is to identify the number of constructs that constituted in the analysis. Table 3 shows the reliability test results for each variable. 
Table 3: Summary Results of Reliability Analysis

\begin{tabular}{lcc}
\hline \hline Variables & Number of items & Cronbach's Alpha Value \\
\hline Attitude & 5 & 0.849 \\
Subjective norm & 6 & 0.783 \\
Perceived behavioural control & 4 & 0.70 \\
Knowledge & 6 & 0.782 \\
Intention & 8 & 0.834 \\
\hline \hline
\end{tabular}

As presented in Table 3, the analysis showed that the Cronbach's Alpha for all five factors are above 0.70 . In particular, the attitude factor is recorded as 0.725 , subjective norm factor is 0.785 , perceived behavioural control factor is 0.704 , knowledge factor is 0.759 , and the intention towards zakat payment as tax rebate factor is 0.833 . As suggested by Hair et al. (2010), the acceptable value of the Cronbach's Alpha is a minimum of 0.7 or more. Therefore, it can be indicated that the items of the intention towards zakat payment as tax rebate provide a significant support in measuring the same underlying construct compared to other items.

\subsection{Validity Analysis}

Table 4 presents the Kaiser-Meyer-Olkin Measure of Sampling Adequacy (KMO) and Bartlett's test of Sphericity for each variable. According to Hair et al. (2010), the recommended value for the KMO should be more than 0.6. Meanwhile, Bartlett's test of Sphericity should be significant $(\mathrm{p}<$ 0.05 ) for the factor analysis to be considered appropriate in the study (Tabachnick \& Fidell, 2007).

Table 4: Summary Results of KMO and Bartlett's Test of Sphericity

\begin{tabular}{lcc}
\hline \hline \multicolumn{1}{c}{ Variables } & KMO & Bartlett's Test of Sphericity \\
\hline Attitude & 0.718 & 0.000 \\
Subjective norm & 0.773 & 0.000 \\
Perceived behavioural control & 0.716 & 0.000 \\
Knowledge & 0.742 & 0.000 \\
Intention & 0.837 & 0.000 \\
\hline \hline
\end{tabular}

As presented in Table 4, the analysis showed that the Kaiser-Meyer-Olkin Measure of Sampling Adequacy (KMO) for all five factors are above 0.60. In particular, the attitude factor is recorded as 0.718 , subjective norm factor is 0.773 , perceived behavioural control factor is 0.716 , knowledge factor is 0.742 , and the intention towards zakat payment as tax rebate factor is 0.837 . As suggested by Hair et al. (2010), the acceptable value of the KMO is a minimum of 0.6 or more. Therefore, it can be indicated that all KMO value were adequate in this study. Meanwhile, Bartlett's test of sphericity also revealed the significant value of 0.000 for all the factors which indicated that correlations between items were significant in this study.

\subsection{Multiple Regression Analysis}

The present study used multiple regression analysis to test the relationship between the independent variables and dependent variables. As presented in Table 5, R square indicates that the variation in the independent variables accounted for $52 \%$ of the variance in the dependent variable. In other words, it portrays $52 \%$ of the variance in compliance intention behavior on paying zakat as a tax 
rebate among taxpayers in Selangor was significantly explained by the variable of attitude, subjective norm, perceived behavioural control and knowledge.

Table 5: Model Summary of Variables

\begin{tabular}{ccccc}
\hline \hline Model & $\mathbf{R}$ & R Square & Adjusted R Square & $\begin{array}{c}\text { Std. Error of the } \\
\text { Estimate }\end{array}$ \\
\hline 1 & $.721^{\mathrm{a}}$ & .520 & .515 & .28818 \\
\hline \hline
\end{tabular}

Table 6 shows regression model reached statistically significant as the p-value for all variables are less than 0.01. Attitude shows a significant effect on compliance intention behaviour of zakat payment as a tax rebate among taxpayers $(\beta=0.290, \mathrm{p}=0.000)$. Attitude also had the highest value (0.290), which means that this variable is the strongest contributor and most significant in explaining the dependent variable among all the independent variables.

Table 6: Multiple Regression Analysis Results

\begin{tabular}{lccc}
\hline \hline Variables & $\begin{array}{c}\text { Standardised Beta } \\
(\boldsymbol{\beta}) \text { Coefficients }\end{array}$ & $\boldsymbol{t}$ & Sig. Value \\
\hline (Constant) & & 7.170 & .000 \\
Attitude & .290 & 5.173 & .000 \\
Subjective Norm & .182 & 3.017 & .003 \\
Perceived Behavioural Control & .196 & 3.853 & .000 \\
Knowledge & .243 & 2.515 & .002 \\
\hline \hline
\end{tabular}

The results also show a significant result for the subjective norm towards the zakat payment as a tax rebate $(\beta=0.182, p=0.003)$. Next, perceived behavioural control indicates a significant effect on the intention of taxpayers to claim zakat payment as a tax rebate $(\beta=0.196, p=0.000)$. Likewise, the variable of knowledge presented the second-best predictor with a beta value of $\beta=0.243$ and $\mathrm{p}=0.002$ on the intention of taxpayers towards zakat payment as a tax rebate. Meanwhile, since the beta values of subjective norm and perceived behavioural control are least among the variables, it means both items make the least contribution to the dependent variable. From the results in Table 6 above, it can be concluded that attitude, subjective norm, perceived behavioural control, and knowledge significantly influence taxpayer's intention in claiming zakat payment as tax rebate. All the proposed hypotheses have been tested and accepted since the p-values for all independent variables are $<0.05$. Results of the hypotheses testing are displayed in Table 7 below.

Table 7: Summary of Results on Hypotheses Testing

\begin{tabular}{lc}
\hline \hline Hypotheses & Results \\
\hline H1: Attitude positively influence taxpayers' intention to claim zakat as a tax rebate. & Supported \\
H2: Subjective norm positively influence taxpayers' intention to claim zakat as a tax & Supported \\
rebate. & \\
H3: Perceived behavioural control positively influence taxpayers' intention to claim & Supported \\
zakat as a tax rebate. & Supported \\
H4: Knowledge positively influence taxpayers' intention to claim zakat as a tax rebate. & Super \\
\hline \hline
\end{tabular}




\section{CONCLUSION}

The aim of this study is to examine the factors that influence individual Muslim taxpayers' intention in claiming zakat payment as a tax rebate. The three TPB variables (i.e. attitude, subjective norm and perceived behavioral control) and knowledge were tested as the variables. The results of analyses showed that all the variables had a positive influence on the intention of taxpayers to claim zakat payment as tax rebate.

The results also showed that attitude was the strongest factor that influence taxpayers' intention to claim zakat as a tax rebate with a beta value of 0.290. This shows that Muslim taxpayers have a positive attitude towards this system. This finding is in line with those of the previous studies in zakat and tax compliance behaviour, which is attitude is believed to have a direct effect in performing the intention and behaviour (Kusumawati et al., 2014). This finding is also consistent with previous research by Khaddafi et al. (2014), which investigated traders' attitude towards their intention to pay zakat on commerce. Taxpayers' positive attitude is vital to ensure the sustainability of the system.

The zakat rebate system encourages higher zakat collections for distributions to unfortunate people that will improve economic and social development. However, in recent years, trust to the zakat authorities has become an issue to zakat payers' compliance. Muhammad (2016) found that taxpayers paid zakat directly to asnaf due to lack of trust to the zakat authorities. This could lead to lower zakat payment to zakat authorities and unfair zakat distributions. The issue of trust to zakat institution is not new in Malaysia, but also in other countries like Indonesia (Tsalas et al., 2019) and Yemen (Obaid et al., 2020). Zakat payers request for more transparency by zakat authorities, particularly on the details of zakat distributions and zakat recipients (Saad, Wahab, \& Hussain, 2016; Saad \& Al-Foori, 2020). Lack of trust to the zakat authorities could discourage zakat payers to pay zakat to authorities which could lead to lower utilisation of the zakat rebate system. The zakat rebate system can be sustained with continuous support from the zakat payers which significantly related to zakat payers' attitude. Future research should examine the relationship between trust to the zakat authorities with zakat payers' attitude.

In regard to subjective norms, it refers to the belief that taxpayers' intention to claim zakat as a tax rebate is influenced by other people such as family members and friends. Since this finding provides an early contribution to the zakat rebate literature, limited previous studies show similar results to this present study. Nevertheless, this finding is consistent with that of the previous studies on tax and zakat compliance behavior - subjective norm is believed to have a positive relationship with the intention and behaviour of the people (Amilahaq \& Ghoniyah, 2019; Khaddafi et al., 2014; Mokhtar et al., 2018; Shaharuddin et al., 2012). From the results, it can be assumed that taxpayers will claim zakat payment as a tax rebate if they are being asked by other people around them or when people surrounding them have big expectations towards them. Nevertheless, the environment around taxpayers makes people's decision to pay zakat and claiming tax rebate tends to be like a personal matter.

Next, the results indicated that perceived behavioral control has a positively influence on the intention of Muslim taxpayers in claiming zakat as tax rebate. The perceived behavioral control is described as the ability of Muslim taxpayers to claim zakat as tax rebate. The findings conclusively showed that Muslim taxpayers will only claim zakat payment as tax rebate if they have the 
capability. Nevertheless, it is worth to note that the capability will change depending on the situation. In other words, Muslim taxpayers will perform the behavior voluntarily if they found that the procedures of claiming zakat as tax rebate are easy to adhere. On the other hand, their tendency to not claim zakat as tax rebate is high if they perceived the procedures to be difficult. In claiming zakat rebate, the procedure is similar with claiming tax reliefs, for example, purchased of computer and subscription of internet under lifestyle relief. A taxpayer must have the original receipt and the receipt is issued under the taxpayer's name, except for zakat fitr. Taxpayers can claim zakat rebate on any types of zakat on wealth paid to zakat authorities. The IRBM also allowed taxpayers to replace their monthly tax deduction with zakat payment. The employer should set-off zakat payments through salary against the amount of tax to be deducted for the respective month. This alternative provides better ability for taxpayers in claiming zakat rebate.

For knowledge, the results showed that it was the second strongest variable that influence taxpayers to claim zakat as a tax rebate with beta value of 0.243 . The positive relationship between knowledge and taxpayers' intention is consistent with the study conducted by Al-Mamun and Haque (2015). The results indicate that Muslim taxpayers will claim zakat as a tax rebate in tax assessment if they are equipped with knowledge. For example, the tendency in claiming zakat as tax rebate will be higher if they are aware that the system will relieve them from the burden of "double taxation". The replacement of monthly tax deduction with zakat payment could be a factor for taxpayers under the employment contract have better knowledge on zakat rebate. Employers can play a significant role to promote and encourage Muslim taxpayers to pay zakat; not only to ensure they perform their duties as a Muslim but also to reduce their financial burden. Other than that, tax education should be introduced to all higher education students because improvement in tax education has a significant effect on tax compliance (Kurniawan, 2020).

This study contributes to the limited research on the integration of zakat and tax in the Malaysian tax system. Furthermore, this study adds value to the tax rebate literature as it is an early study that examined the factors influencing taxpayers' intention to claim zakat payment as a tax rebate. This study could help other researchers in finding new ways to improve the attitude, awareness, and knowledge of Muslims taxpayers of the incentives provided by the government. In terms of practice, the findings of this study could help the IRBM and Malaysian zakat institutions in their attempt to understand the behaviour of Muslim individual taxpayers in claiming zakat payment as a tax rebate. This study will also provide insights to the IRBM on the effectiveness of the zakat rebate system, which has been implemented for more than 20 years. It is hoped that the IRBM will publish reports on zakat rebate claimed by taxpayers for further research particularly on demographic factors and 'lost' of government revenue from income tax collection.

This study has several limitations. First, the sample was collected only in Selangor. Malaysian taxpayers are widely spread out, including those in other states, including Sabah and Sarawak. The second limitation refers to the response bias of the respondents, which is expected as Malaysian taxpayers from different backgrounds might respond to the questionnaire differently. Some of the respondents might have a full understanding of the tax rebate system provided by the government, but some might not. Therefore, the evaluation made by the respondents may not be accurate due to the different levels of understanding of the system. The final limitation of this study is the scarcity of existing empirical literature on the integration of zakat and tax in the tax system, especially on TPB. Previous literature is essential for the researchers to understand the issues and identify the gaps in previous studies. For future research, the sample size should be broadened to 
other states such as Johor, Sabah, Sarawak and Kedah. By doing so, it would increase the level of accuracy of the data obtained with a larger sample size of respondents. Future researchers should also examine other variables for example trust to the government and trust to the zakat authorities. Qualitative research methodology can be adopted to further understand taxpayers' intention in claiming zakat as a tax rebate.

\section{ACKNOWLEDGEMENT}

The researchers would like to convey our gratitude to the Ministry of Higher Education for funding the research under Research Grant No. USIM/FRGS/FEM/32/50415. We also want to express thanks to the respondents and researchers who gave comments to improve the research findings.

\section{REFERENCES}

Al-Mamun, A., \& Haque, A. (2015). Perception of Muslim Consumers Towards Tax Deduction Through Zakat in Malaysia: An Empirical Investigation on Muslims In Malaysia. 1st International Conference on Shari'ah Oriented Public Policy in Islamic Economic System Proceedings (ICOSOPP 2015) (pp. 532-549). Acheh, Indonesia.

Abashah, A., Samah, I. H. A., Saraih, U. N., Rashid, I. M. A., Ramlan, N., \& Radzi, W. N. S. W. M. (2018). The Impact of Attitude and Subjective Norms towards Zakat Compliance Behaviour in Malaysia. International Journal of Engineering \& Technology, 7(3), 171-174.

Ajzen, I. (1991). The Theory of Planned Behaviour. Organizational Behaviour and Human Decision Processes, 50(2), 179-211.

Ajzen, I., \& Fishbein, M. (1980). Understanding Attitudes and Predicting Social Behaviour. Englewood Cliffs, NJ: Prentice-Hall.

Amilahaq, F. \& Ghoniyah, N. (2019). Compliance Behaviour Model of Paying Zakat on Income Through Zakat Management Organizations. Jurnal Ekonomi dan Keuangan Islam, 8(1), $114-$ 141.

Bakar, N. B. A., \& Rashid, H. M. A. (2010). Motivations of Paying Zakat on Income: Evidence from Malaysia. International Journal of Economics and Finance, 2(3), 76-84.

Bidin, Z., Idris, K. M., \& Shamsuddin, F. M. (2009). Predicting Compliance Intention on Zakah on Employment Income in Malaysia: An Application of Reasoned Action Theory. Jurnal Pengurusan, 28, 85-102.

Damayanti, T. W., Sutrisno, T., Subekti, I., \& Baridwan, Z. (2015). The Role of Taxpayer's Perception of the Government and Society to Improve Tax Compliance. Accounting and Finance Research, 4(1), 180-187.

De Bruijn, G.-J. (2010). Understanding College Students' Fruit Consumption. Integrating Habit Strength in The Theory of Planned Behaviour. Appetite, 54(1), 16-22.

Eagly, A. H., \& Chaiken, S. (1993). The Psychology of Attitudes. Fort Worth: Harcourt Brace Jovanovich.

Farah, J. M. S., Shafiai, M. H. B. M., \& Ismail, A. G. B. (2019). Compliance Behaviour of Zakat Donation: A Qualitative Approach. IOP Conference Series: Materials Science and Engineering, 572, 1-8.

Fishbein, M., \& Ajzen, I. (1975). Belief, Attitude, Intention, and Behaviour: An Introduction to Theory and Research. Reading, MA: Addison-Wesley. 
Grant, R. M. (1996). Prospering in Dynamically Competitive Environment: Organizational Capability as Knowledge Integration. Organization Science, 7(4), 375-387.

Hair, J. F. Jr., Black, W.C., Babin B. J., \& Aderson R. E. (2010). Multivariate data analysis: A global perspective ( $7^{\text {th }}$ ed.). Boston, MA: Pearson Educational.

Huda, N., Rini, N., Mardoni, Y. \& Putra, P. (2012). The Analysis Of Attitudes, Subjective Norms, and Behavioral Control On Muzakki's Intention to Pay Zakah. International Journal of Business and Science Social, 3(22), 271-279.

Inland Revenue Board of Malaysia. (IRBM) (2015). Annual Report 2015. Kuala Lumpur, Malaysia.

Kamil, M. I. (2002). Kesan Persepsi Undang-Undang Dan Penguatkuasaan Zakat Terhadap Gelagat Kepatuhan Zakat Pendapatan Gaji. Journal of Ethics, Legal and Governance, 2(2006), 32-41.

Khaddafi, M., Heikal. M., \& Falahuddin. (2014). The Intention to Pay Zakat Commercial: An Application of Revised Theory of Planned Behaviour. Journal of Economics and Behavioural Studies, 6(9), 727-734.

Kogut, B \& Zander, U. (1992). Knowledge of The Firm, Combinative Capabilities and The Replication Of Technology. Organization Science, 3(3), 383-397.

Kurniawan, D. (2020). The Influence of Tax Education During Higher Education of Tax Knowledge and Its Effect on Personal Tax Compliance. Journal of Indonesian Economy and Business, 35(1), 57-72.

Kusumawati, A., Halim, A., Said, D. \& Mediaty. (2014). Effect of Intention Mediation Towards Attitude, Subjective Norms and Perceived Behavioral Control on Taxpayers' Behavior. Journal of Research in Business and Management, 2(10), 26-32.

Linden, S. v. d. (2011). Charitable Intent: A Moral or Social Sonstruct? A Revised Theory of Planned Behaviour Model. Current Psychology, 30, 355-374.

Mikesell, J. (2003). Fiscal Administration: Analysis and applications (6 $6^{\text {th }}$ ed.). California, Wadsworth Publishers.

Mokhtar, S. S. S., Mahomed, A. S. B., \& Hashim, H. (2018). The Factors Associated with Zakat Compliance Behaviour Among Employees. International Journal of Economics and Management, 12(S2), 687-696.

Muhammad, I. (2016). Factors that Influence Business Zakat Compliance among Small and Medium Entrepreneurs. The Journal of Muamalat and Islamic Finance Research, 13(1), 97110.

Muhammad, I., Nor, N. S. M., \& Rahman, A. A. (2017). Kedudukan Zakat Sebagai Rebat Cukai Pendapatan Dalam Akta Cukai Pendapatan 1967. In Z. M. Musa, A. A. Rahman, A. A. Wahab (Eds.), Memperkasa Kutipan dan Agihan Zakat di Malaysia (pp. 157-163). Universiti Sains Islam Malaysia.

Mukhlis, I., Utomo, S. H., \& Soesetio, Y. (2015). The Role of Taxation Education on Taxation Knowledge and Its Affection Tax Fairness as well as Tax Compliance on Handicraft SMEs Sectors in Indonesia. International Journal of Financial Research, 6(4), 161-169.

Obaid, M. M., Ibrahim, I., \& Udin, N. M. (2020). Zakat and Tax Compliance Behaviour in Yemen: A Conceptual Study. Journal of Advanced Research in Business and Management Studies, 19(1), 1-14.

Palil, R., Akir, R. \& Ahmad, F. (2013). The Perception of Taxpayers on Tax Knowledge and Tax Education with Level of Tax Compliance: A Study the Influences of Religiosity. ASEAN Journal of Economic Management and Accounting, 1(1), 118-129. 
Pappas, N. (2016). Marketing Strategies, Perceived Risks, and Consumer Trust in Online Buying Behaviour. Journal of Retailing and Consumer Services, 29, 92-103.

Pickens, J. (2009). Attitudes and Perceptions. In N. Borkowski (Ed.), Organizational Behavior in Health Care (pp. 43-76). Sudbury, MA: Jones and Bartlett Publishers.

Ramayah, T., Yusoff, Y. M., Jamaludin, N., \& Ibrahim, A. (2009). Applying the Theory of Planned Behaviour (TPB) to predict Internet Tax Filling Intentions. International Journal of Management, 26(2), 272-284.

Rotter, J. B. (1966). Generalized Expectancies for Internal Versus External Control of Reinforcement. Psychological Monographs, 80, 1-28.

Saad, A. Y. Q., \& Al-Foori, A. M. (2020). Zakat and Tax: A Comparative Study in Malaysia. International Journal of Innovation, Creativity and Change, 10(12), 140-151.

Saad, N. (2012). Tax Non-Compliance Behaviour: Taxpayers' View. Procedia Social and Behavioral Sciences, 65, 344-351.

Saad, R. A. J., Wahab, M. S. A., \& Hussain, M. H. M. (2016). Perceived Service Quality of Zakat Institution Among Muslim Businessmen in Malaysia. Proceedings of the $3^{\text {rd }}$ International Conference on Applied Science and Technology (ICAST'18) 2016 (pp. 020125-1 - 0201254). US: AIP Publishing.

Salkind, N. J. (2014). Statistics for People Who (Think They) Hate Statistics $\left(5^{\text {th }}\right.$ ed.). Thousand Oaks, CA: SAGE Publications, Inc.

Samad, M. N., Ariff, M., \& Nassir, A. M. (2016). Impact of Zakat Payment Offset System on Income Tax Collection in Malaysia. International Journal of Applied Business and Economic Research, 14(13), 9579-9607.

Sapingi, R., Ahmad, N. \& Mohamad, M. (2011, March). A Study on Zakah Of Employment Income: Factors that Influence Academics’ Intention to Pay Zakah. Proceedings of the 2nd International Conference on Business and Economic Research (2nd ICBER 2011).

Shaharuddin, N. S., Palil, M. R., Ramli, R., \& Maelah, R. (2012). Sole Proprietorship and Tax Compliance Intention in Self-Assessment: A Theory of Planned Behavior Approach. International Journal of Business, Economics and Law, 1, 34-42.

Shook, C., \& Bratianu, C. (2010). Entrepreneurial Intent in a Transitional Economy: An application of the Theory of Planned Behaviour to Romanian students. International Entrepreneurship and Management Journal, 6(3), 231- 247.

Singh, V. (1998). Self-Assessment: Issues with regard to self-assessment. Journal of Malaysian Institute of Taxation, 87, 4-6.

Tabachnick, B. G., \& Fidell, L. S. (2007). Using Multivariate Statistics (5th ed.). Boston MA: Pearson Education, Inc.

Tsalas, N. A., Mahri, A. J. W., \& Rosida, R. (2019). Zakat Compliance Behaviour: Good Crorporate Governance with Muzakki’s Trust Approach (Survey on Muzakki of the National Board of Zakat (Baznas) in Garut). KnE Social Sciences, 3(13), 796-808. https://doi.org/10.18502/kss.v3i13.4248

Zainol, B. (2008). Faktor-Faktor Penentu Niat Gelagat Kepatuhan Zakat Pendapatan Gaji (Unpublished $\mathrm{PhD}$ thesis). Universiti Utara Malaysia (UUM). 